\title{
MUSLIM STUDENT EXPECTATIONS FROM ISLAMIC STUDIES COURSES IN AUSTRALIA
}

\author{
Mehmet Ozalp* and Tamana Daqiq**
}

\begin{abstract}
In 2009, the Islamic Sciences and Research Academy of Australia (ISRA Australia) partnered with Australia's Charles Sturt University to establish the Centre for Islamic Studies and Civilisation (CISAC). From 2011, CISAC began offering undergraduate and graduate courses combining traditional higher Islamic learning with the modern quality standards of tertiary-level education. Since the opportunity to study Islam in an Australian university is rare, CISAC has attracted students from a diversity of age, ethnic and educational backgrounds, and with wide-ranging academic skills and motivations. While such diversity sets a unique opportunity, it also poses challenges for educators in terms of course design, approaches to learning and student services. For this study, we surveyed 360 students from CISAC to determine their motivations for undertaking undergraduate and postgraduate degrees in Islamic Studies and the expectations they had from those courses. It was found that, by providing a holistic Islamic higher education within a structured and measured university model, CISAC has filled a unique gap. Also, whilst the vast majority of students seek to gain a well-rounded Islamic education, a small number undertake CISAC courses with the aim of pursuing further study. In that context, we concluded that CISAC needs to supply supplementary traditional scholarly programmes for those students who wish to go further. The study also highlights the importance of student engagement and feedback as a means of adequately meeting the demands of those students pursuing Islamic Studies in the West.

Keywords: Islamic Studies, Islamic Studies in the West, Islamic higher education, Muslim students, Islam in university, Islam in Australia, Islamic Studies at CSU, ISRA, CISAC
\end{abstract}

\section{Introduction}

The latter half of the twentieth century saw Muslims migrate to the West en masse. Though migration in itself poses its own challenges, for the Muslim community these have been further confounded (particularly in recent decades) by a climate of political tension and mistrust. Nevertheless, difficult circumstances often give rise to creative solutions; in response to these problems, there are now visible signs of a burgeoning Western Muslim community made up of youthful, intellectual, faithful and highly active individuals. Of most significance, these 
developments have also seen the community return to tradition and Islamic education. As a result, and since the late 2000s, momentum has shifted towards a growth in avenues for Islamic higher education in the West.

In light of the fact that Islamic studies is a relatively new phenomenon in the West, emerging only in the mid-twentieth century, ${ }^{1}$ the literature on formal Islamic education in a Western context is limited, being particularly narrow with respect to Islamic higher education. Nevertheless, to facilitate a coherent and thorough discussion, the paper will begin with an examination and evaluation of the limited amount of literature which does exist surrounding, firstly, Islamic education and, secondly, the students of Islamic education.

\section{Islamic Education}

Thus far, most of the literature on Islamic education has focused on the growth and rise of Islamic studies as a university-based discipline distinct from Near Eastern and Middle Eastern studies. Kurzman and Ernst, for example, illustrate this with their historical account and statistical analysis of the rise of Islamic studies in different university departments in the United States. ${ }^{2}$ They explain how the various approaches to Islamic studies in American universities have been influenced by the objectives of the departments in which they are housed, particularly as a way to address the shortcomings of existing Islam-focused courses.

In a similar vein, Johns explores the history of Islamic studies in the Australian context. He highlights shortcomings in both content and approach, often attributed to the lack of expertise in traditional Islamic sciences exhibited by academic staff. Johns also discusses the twentieth-century political climate that helped shape the Australian approach to Islamic studies, identifying Australia's relationship with Indonesia as a key driver for engaging in the discipline. ${ }^{3}$

An in-depth discussion of the objectives of Islamic education in the West is found in Kazmi. ${ }^{4}$ Kazmi presents a critical analysis of diverse objectives for Islamic education, ranging from Islamisation to critical thinking, the latter of which he strongly favours. In presenting his arguments, Kazmi goes to great lengths to support Fazlur Rahman's propositions for an educational system that creates Muslim thinkers. ${ }^{5}$

Critiques of Islamic studies in Western institutions, and particularly in Australia, are often informed by studies conducted in Southeast Asia by way of a cross-comparative analysis. ${ }^{6}$ Making Modern Muslims is one such study that seeks to shed light on the varieties of Islamic institutions and their curricula in Southeast Asia. ${ }^{7}$ Similarly, Pohl looks at the effects of Indonesia's Islamic education on students' participation in the public sphere. ${ }^{8}$ It is critical to note, 
however, that like most studies of this kind, ${ }^{9}$ Pohl's paper focuses primarily on secondary education; only a few exceptions, such as Lukens-Bull's research, ${ }^{10}$ examine the debates surrounding Islamic higher education in Indonesia.

The discussion so far has highlighted the fact that the literature on Islamic higher education, whether in a Western context or elsewhere, is primarily dedicated to historical, critical and statistical analyses of the quality and quantity of Islamic tertiary education. Western academics' general lack of proper understanding of the Islamic scholarly tradition, coupled with their sociopolitical approaches, essentially limit the way Islam is studied in the higher education sector.

\section{Students of Islamic Education}

There is a large amount of research on Muslim student experience in the Western secondary and tertiary education systems. In separate studies, Asmar, ${ }^{11}$ Donohoue, ${ }^{12}$ and Asmar, Proude and Inge ${ }^{13}$ examine the challenges faced by Muslim students in the Western education system. However, there are presently no studies examining Muslim student responses and attitudes to Islamic studies specifically.

An examination of the literature also reveals some scholarly interest in educating host populations about Islam and Muslims, particularly in light of ongoing media misrepresentation and growing hostility towards Muslim communities in the West. Ata and Windle, for example, examine the role of Australian schools in educating non-Muslim students about Islam and Muslims. They conclude by demonstrating that Australia's (particularly secondary) schools generally provide students with little knowledge about Islam, resulting in a student body that is apt to display a degree of prejudice towards Muslims. ${ }^{14}$ In their study, however, it is critical to note that 'Islamic education' means education about Muslim culture, rather than about Islam as a faith tradition. Their study is nevertheless useful for addressing the attitudes of non-Muslim students towards Muslims and Islam. However, there are few studies concerned with Muslim and/or non-Muslim student attitudes towards Islamic tertiary education in the West.

\section{Identified Gaps}

The opportunity to provide a holistic Islamic education in a Western context is a new development and poses unique challenges, of which the production of appropriate course designs capable of meeting student expectations is perhaps the most difficult. In light of the above literature review, this paper aims to address the various gaps in previous research by shedding empirical light on the 
motivations and expectations of students who undertake Islamic higher education courses in Australia. It shall do this by using the strategies, achievements and challenges of course design in Charles Sturt University's CISAC as a case study. More specifically, we evaluate the outcomes of a 2014 survey of CISAC students aimed at elucidating student expectations with regards to course content and outcomes.

\section{Islamic Education in the West}

\section{Factors Contributing to the Demand for Islamic Education in the West}

An examination of the Australian context highlights a growing number of schools, mosques and universities offering Islamic education. Indeed, this is not just the case in Australia, but also in many other Western countries, where Muslims have established significant minority populations since World War II. But in Australia specifically, the past 30 years have seen Muslims establish 52 private schools, serving an estimated 30,000 students. Moreover, scholarly interest in Islamic studies in the West has also increased over the same period, particularly post9/11. As a consequence, there has been a sharp rise in Islamic studies-themed doctoral dissertations and in the number of journal articles dedicated to Islam. ${ }^{15}$ But, what factors have contributed to this increased interest in Islam in the West?

The increasingly large Muslim populations of many Western countries are perhaps the most significant factor. Thus, it is noteworthy that Islam is the fastest growing religion in the world, ${ }^{16}$ a statistic which also extends to Australia. There the Muslim population, albeit still very much a minority, currently constitutes $2.2 \%$ of the 21.6 million-strong population. ${ }^{17}$ It is, however, growing at a rapid rate, mainly through birth and migration, with Islam now being the third largest religion in Australia after Christianity and Buddhism. ${ }^{18}$ Naturally, the increasing Muslim population is a critical factor in the growing need for Islamic education, both in general and in higher education in particular.

In addition to population growth, the level of education amongst Muslims in Australia is above the national average. As the Muslim community matures, more parents are becoming professionals who are fully conversant in the language and culture of their host society, thereby increasing the literacy and educational levels of their children. Another key factor in the increase in Muslim educational attainment is the establishment of Islamic colleges. The aim of many Muslim families has been to maintain their Islamic identity. This, coupled with the Australian Federal Government's funding policy towards private schools, has facilitated the establishment of a rapidly-growing Islamic secondary education sector. The competitive nature of this sector, which entails that schools need to 
market themselves and their success in order to attract parents, has increased rates of high school completion. Because most of these schools are faith-based, with a strong emphasis on learning and teaching Islam, a significant portion of their graduates decide to pursue Islamic disciplines alongside other secular tertiary courses.

Without doubt, another significant factor behind the rise in demand for Islamic education is the Islamic tradition's inherent emphasis on gaining knowledge. ${ }^{19}$ Coupled with this attribute, the growing prestige associated with being a Muslim scholar in the modern world, where Islam and Muslims are under constant media scrutiny, pose an additional motivation behind the demand for Islamic education.

Furthermore, the religious, social and cultural challenges facing Australia's growing Muslim population requires the development of creative solutions capable of encouraging community leaders and general adherents of the faith to serve their community and religion. ${ }^{20}$ Such service cannot be adequately rendered without a grounded understanding of the Islamic faith and its various disciplines, as gained through an Islamic education. In an Australian context, this raises the increased use of English in Islamic education and its impact on the accessibility of that education for peoples of diverse age groups, ethnicities and educational levels.

The above factors are just a few among many that have contributed to the overall increase in the number of Muslims studying Islam in Australia. This increase has become particularly pronounced in higher education in recent years and is anticipated to become more rapid in the future. The establishment of ISRA Australia and CISAC has demonstrated to the Australian Muslim community that providing Islamic higher education in a Western context is possible.

\section{Two Distinct Approaches to Islamic Education}

To adequately contextualise and appreciate the needs of students studying Islam in the modern Australian context, it is critical to examine the nature, approach and history of Islamic education in that country.

Since the tenth century, madrasas have been the primary providers of education in the Muslim world. Although the nineteenth-century introduction of Western-influenced educational institutions led to a decline in madrasa-style institutions, they nevertheless survived in many Muslim countries, and from whence they were later exported to the West. As such, Islamic studies in Australia has traditionally gravitated towards a madrasa-style education, mainly due to its low cost, invisibility to regulation, and esteemed reputation amongst Muslim scholars. This has resulted, however, in a heavy distinction between madrasastyle and university-style education models in the Western context. 
Madrasa-style education is characterised by the study of traditional Islamic sciences, including tafsir (exegesis), the Qur'an, hadith (Prophetic traditions), fiqh (Islamic law) and usuli (foundational methodology), alongside Arabic and logic. The advantages of this style of education include: its focus on usuli and principle-based disciplines, such as usul al-fiqh (jurisprudence) and usul al-hadith (principles of hadith studies); its greater emphasis on Arabic and, therefore, access to classical texts; and its thorough coverage of the Qur'an and hadith literature. All these features of a madrasa-style education allow students to become well-grounded in tradition Islamic learning.

However, a madrasa-style education also carries many disadvantages, and which become particularly apparent in the Western context. These include: a limited curriculum, usually constituting only classical disciplines; poorly designed or entirely absent assessment; an over-emphasis on information recollection and memorisation; and a limited focus on research skills and critical thinking. Madrasas also fall outside the formal Western educational system and its quality assurance processes, meaning that students receive no acknowledgement of their achievements by way of qualifications, accreditation or other awards. Accordingly, while madrasa-style Islamic education gives an excellent grounding in tradition, graduands are usually not well prepared for entering society, particularly given that they have received no formal acknowledgement of their efforts or standard of education.

Suffice it to say, therefore, that a madrasa-style education is largely inadequate for Australia's growing Muslim population. It fails to provide a comprehensive curriculum capable of addressing contemporary and traditional disciplines.

To some extent, however, the limitations of a madrasa-style education have been addressed by the Islamic studies programmes taught at universities. However, a brief examination reveals various shortcomings here also. Arguably, the most significant of these lies in the Orientalist-based perspectives of the university departments dedicated to Middle Eastern and Near Eastern languages and civilisations, in which Islamic studies as a discipline is often housed. Orientalist approaches to Islam, and the non-Muslim academics who espouse them, do not share Muslim sensitivities and priorities. According to Kurzman and Ernst, the range of subjects covered in these departments, extending from "cuneiform civilizations of ancient Mesopotamia to medieval Islam and Judaism and eventually to the contemporary literatures of the Middle East," indicate that they are "loose collections of linguistic and textual expertise housed together for convenience because of their geographic association" rather than any shared intellectual perspective. ${ }^{21}$ There is also an apparent over-emphasis on Semitic studies in these departments. ${ }^{22}$ 
In addition, the courses offered often exhibit an exaggerated emphasis on culture and politics, rather than Islam as a faith tradition. Interestingly, Australian universities have traditionally only embarked on Islamic studies through the prisms of cultural studies, politics and the Arabic language. As a result, Muslims generally do not trust the courses Western universities offer on Islam, often feeling frustrated by a lecturer's lack of knowledge and reliance on media representations. Indeed, Kurzman and Ernest note how increased student interest and demand for courses in Islamic studies have led some scholars to add this subject to their list of expertise, despite a lack of formal training in the field. Moreover, graduand knowledge of the traditional Islamic sciences of Qu'ran, hadith, tafsir, fiqh and Arabic, all of which are central to understanding Islam as a faith tradition, are often inadequate or completely lacking.

Hence, it seems reasonable to argue that, in order to provide a comprehensive Islamic studies course for students, an exigent need exists to bridge the chasm between the madrasa and university styles of education prevalent in both the Australian and broader Western contexts. It was with this specific intent in mind that ISRA Australia partnered with Charles Sturt University to establish CISAC and design a series of new bachelor's and master's degree courses on Islam.

\section{Case Study of CISAC}

\section{Synthesis of two Educational Systems}

In 2010, ISRA Australia set out to combine the advantages of the madrasa system with those of a modern university. To achieve this aspiration, ISRA Australia signed a partnership agreement with Charles Sturt University to establish CISAC, the vehicle through which the first university-accredited courses by an Islamic Australian institution would be delivered.

The agreement between the two institutions was built on a high degree of mutual trust developed over time, through dialogue initiatives. Critically, the key terms of the written agreement would be foundational to both the design of future courses and to how those courses would be perceived by the intended audience - that is, by students of Islamic higher education, the majority of whom would be Muslims.

Some key aspects of the agreement included: ISRA Australia was to have control over course content while Charles Sturt University was to provide quality assurance; ISRA Australia was to select its management and teaching staff in accordance with the university's qualification criteria; and ISRA Australia would raise and manage its own budget while the university would only provide funding based on student load. In this way, ISRA Australia ensured the Islamic integrity of what was taught while meeting the university's quality standards. 
This division of responsibility would ultimately have a two-tiered effect. On the one hand, it was critical in addressing the traditional mistrust some Muslims felt towards Islamic courses offered by Western universities. On the other, involvement of the university avoided the deficiencies in quality and standards historically characteristic of the madrasa-style system. This synthesis between the two educational systems was coherently captured in the agreement.

\section{Course Design and Graduate Attributes - Initial Approach}

CISAC's Islamic studies course design has three core components: classical Islamic sciences, contemporary academic liberal arts, and human development and leadership. The combination of these three components has ensured a balance between traditional and contemporary disciplines, developing a grounding in the Islamic tradition while also furthering leadership and personal skills.

Numerous challenges were encountered while developing these courses. These included: cost of delivery for the department; the cost of study for students; breadth and depth of disciplines covered; limits on number of units covered in each course; various university policies; availability of sufficiently qualified teaching personnel; adequately meeting the Australian Qualifications Framework standards; and uncertainty about potential student numbers. These challenges informed course design and continue to be negotiated when developing and improving courses.

To deliver courses meeting the objectives of both institutions, it was also critical to consider, adapt and promote the university's desired graduate attributes for those studying Islamic studies. The university's graduate attributes predominantly focus on acquiring key academic skills and building a student's capacity to contribute to their community and wider society. Some of the desired graduate attributes include:

Demonstrate a broad overview of their field of knowledge; communicate effectively in a manner relevant to their discipline; demonstrate analytical skills including the exercise of critical and reflective judgement; address unfamiliar problems; plan their own work; work as a member of a team; demonstrate a national and international perspective; and demonstrate an understanding of, and commitment to, values-driven practice in their field of study that takes account of open enquiry, ethical practice, social justice, cultural diversity, reconciliation and environmental sustainability. ${ }^{26}$

While these attributes cover liberal arts and address the multicultural nature of Australian society, students of Islam need additional and more specific attributes on graduation. Therefore, ISRA Australia added further attributes 
capable of satisfying those needs. These included: demonstrate well-grounded knowledge and understanding of foundational Islamic disciplines; demonstrate an understanding of Islam's middle-path and inclusive approach; demonstrate knowledge of the various national and international perspectives concerning how to approach religion and its application in the modern world; demonstrate an ability to address existing and emerging problems and issues relating to Islamic practice in the modern world; develop and demonstrate an understanding of Islam that is in tune with intercultural and interfaith peace and harmony; embody Islamic values and principles within the Australian multicultural context; and demonstrate a sense of responsibility to serve not just the Muslim community, but also Australian society and humanity more generally.

The key challenge thereafter was to determine how to effectively inculcate these graduate attributes into the greatest number of students using a finite course. But, while the bachelor's and master's courses were designed with these attributes in mind, an integral consideration in course design remained a fuller consideration of the broader needs and expectations of students. By the end of 2013, CISAC had received three annual student cohorts and was in a position to determine these needs and expectations more accurately. The starting point for doing this was to have an understanding of student demographics at CISAC.

\section{Student Demographics}

As of 2014, statistics reveal that $56 \%$ of the students are enrolled in the bachelor's programme, $33 \%$ in the master's programme, $8 \%$ in the classical Arabic programme, and the remainder in various other graduate programmes (Figure 1).

\begin{tabular}{|l|r|}
\hline \multicolumn{1}{|c|}{ Course Name } & Active Students \\
\hline Bachelor of Islamic Studies & 197 \\
\hline Master of Islamic Studies & 118 \\
\hline Master of Arts (Classical Arabic) & 28 \\
\hline Master of Arts (Islamic Studies Research) & 2 \\
\hline Graduate Certificate in Islamic Studies & 8 \\
\hline Graduate Diploma of Islamic Studies & 2 \\
\hline Graduate Certificate in Classical Arabic & 3 \\
\hline Graduate Diploma of Classical Arabic & $\mathbf{3 6 0}$ \\
\hline
\end{tabular}

Figure 1: Course enrolments 
The age distribution is quite diverse, with almost half of all students being under the age of 30 , while one quarter are above the age of 40 (Figure 2). Students under 24 years of age make up $28 \%$ of the total, which is encouraging in terms of long-term study potential.

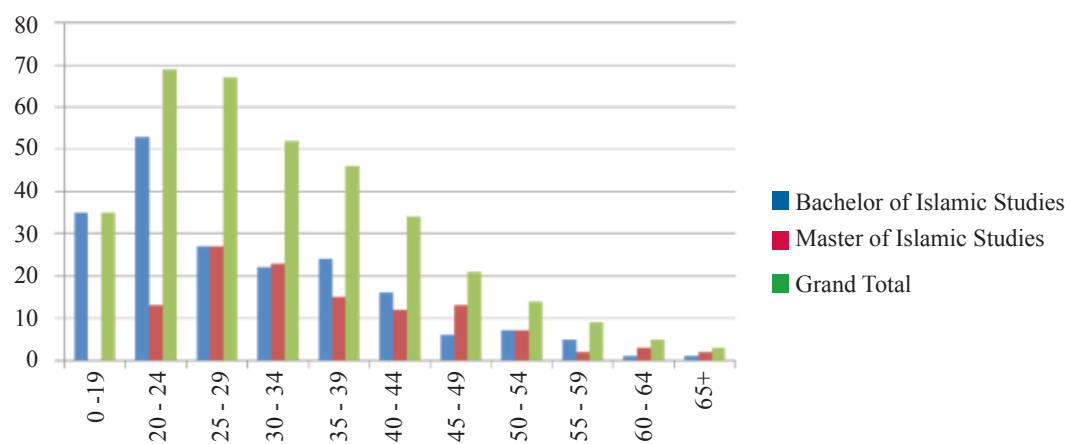

Figure 2: Age distribution

The educational history of students reveals that a large proportion are highly academic (Figure 3). In particular, approximately one-quarter of students on the bachelor's course are currently completing a double degree, primarily because there are few career prospects in Australia for a graduate in Islamic studies, highlighting the need to diversify. Indeed, in some cases students only make the decision to study Islam after they have already enrolled on another bachelor's course. In the master's course, $31 \%$ of students have previously completed another post-graduate qualification (Figure 3). There is a correlation between this figure, the high enrolment on the Master of Islamic Studies course, and the high portion of students over 30 years of age. This student group is generally made up of professional people who are either seeking to augment their existing professional qualifications with another in Islamic studies (although this did not come across as strongly as expected, see Figure 6) or they did not have the opportunity to receive a structured education in Islam earlier in life. 


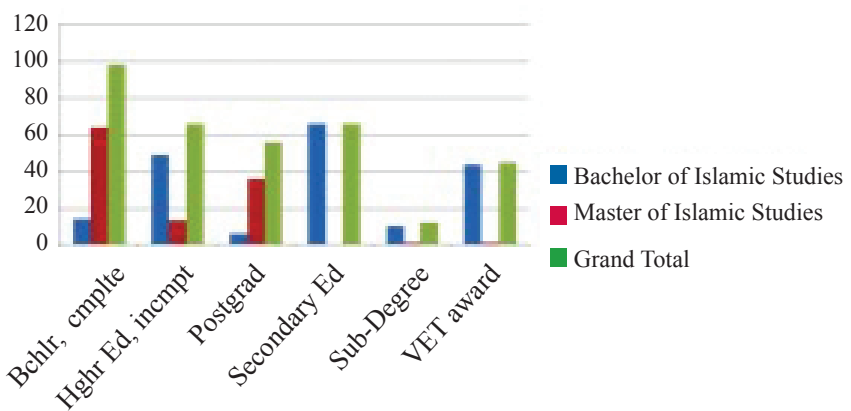

Figure 3: Educational background

Student ethnicities reflect the location of CISAC: $42 \%$ of students were born in Australia and more than half of the rest are of either Lebanese or Turkish heritage (Figure 4). Other ethnicities represented in the student base include Anglo-Saxon, Pakistani, Bangladeshi, Afghani, Bosnian, Malaysian, Indonesian, Burmese and Egyptian. The ethnic diversity of the students, and the correlation between that diversity and the ethnic proportions present within the wider Australian Muslim community, indicate the courses' penetration and broad appeal across the Australian Muslim community as a whole.

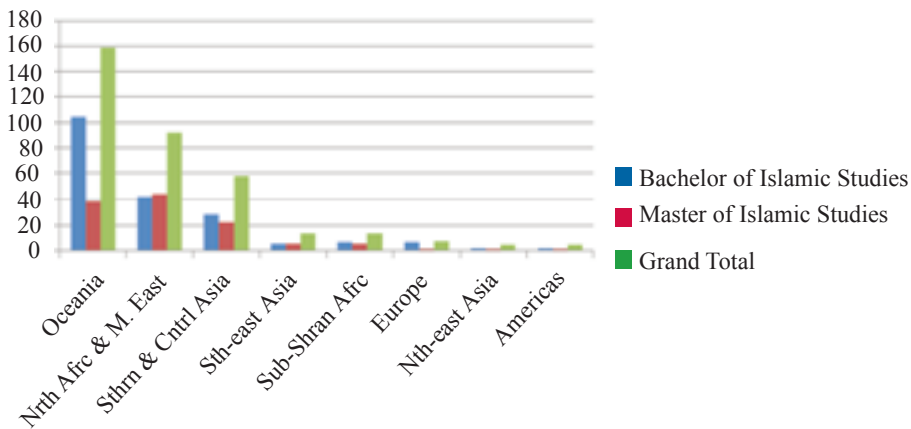

Figure 4: Student ethnic backgrounds

Gender statistics reveal the number of female students to be $22 \%$ greater than the number of male students. Notwithstanding the need for further study to determine the causes and factors associated with this imbalance, some factors are immediately identifiable. For the target student group, there are far more study options to choose from for men than women. ISRA Australia is one of the few organisations that provides adequate support and equal opportunity for women. Considering that $80 \%$ of students in the survey cited busy life and family as a 
barrier to completing courses, men are less likely to take up a long-term and serious study commitment. It also appears that the flexibility in class times and online access to course materials and lectures are conducive to stay-at-home mothers.

A student base with diverse age, gender, ethnicity and educational background, and as indicated by the above statistics, inevitably affects course design and student services. Accordingly, these statistics highlight the need for further flexibility and adaptability of courses and subjects.

\section{Student Expectations from Islamic Studies Courses}

Following three years of consecutively high rates of student enrolment in Islamic studies, improving and adapting course design to meet the needs of future students continues to pose an important imperative and challenge. To gain insight into student expectations, CISAC conducted a survey of its student base in early 2014.

When students were questioned about why they elected to study with CISAC, the overwhelming majority (72\%) stated that their reason was because "it teaches Islam from within the tradition and offers a university degree in Islamic studies." A further $20 \%$ of respondents cited "only organisation to offer university degree in Islamic studies." Such an overwhelming response supports CISAC's value proposition and reinforces the importance of remaining committed to delivering traditional Islamic sciences within a modern university framework, as well as the need to further develop and elucidate key aspects of each component in order to continue to meet student expectations.

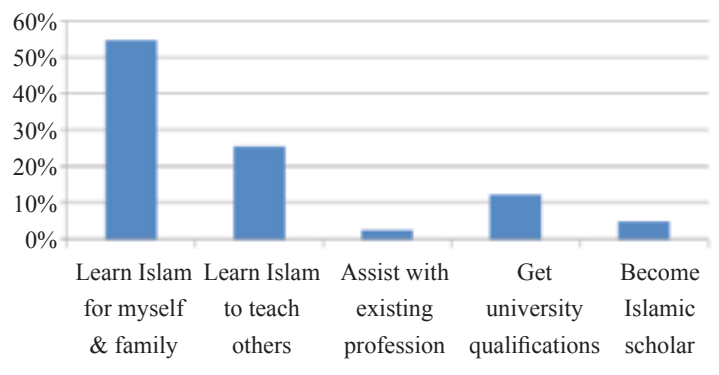

Figure 5: Response to "What is the main reason for you to take an Islamic studies course?"

In order to gauge the aspirations of students, they were questioned about their reasons for undertaking Islamic studies (Figure 5). More than half of the students $(55 \%)$ indicated that they wished to study for themselves and their family, while approximately one-quarter (26\%) aspired to teach Islam to others. 
These responses correlated strongly with the level of Islamic knowledge students aspired to, as $63 \%$ desired either a sufficient level to teach or a good grounding in structured learning (Figure 6).

Interestingly, $27 \%$ of students indicated a desire to achieve a scholarly level of Islamic knowledge. While this is a significant number of students, it is not the majority. It does highlight, however, that students of Islamic studies are diverse not only in age, ethnicity and educational background, but also in aspirations. Hence, these aspirations must be considered when improving and adapting course design and objectives.

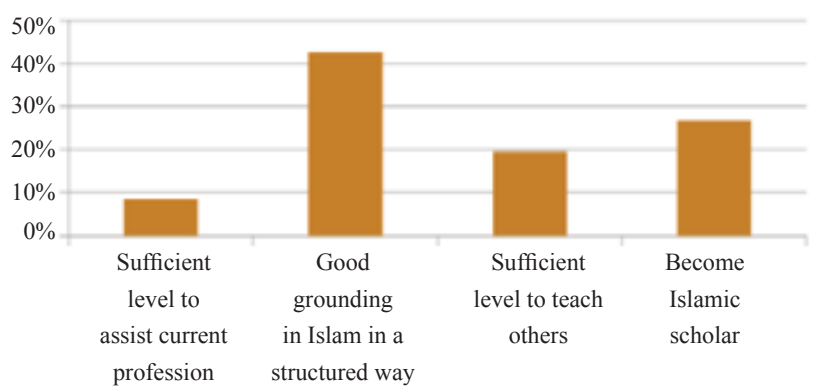

Figure 6: Students' response to "What level of Islamic knowledge did you aim to achieve at the start of the course?"

\section{Course Review in Light of Student Survey}

Following an analysis of the responses to the student survey, CISAC undertook a course review. This resulted in several changes to the courses offered, all designed to further improve those courses by taking into consideration the student expectations not presently being met by them.

To maintain a strong commitment to teaching Islam from within the tradition, identified by students as a key factor in their decision to study with CISAC, ten core subjects were identified as essential. These constituted usuli subjects, theology and the study of sources such as the Quran and hadith. The remaining undergraduate subjects were set as electives and a decision was made to further build the list of elective subjects over time, as staff and student numbers justified. To both cater for diversity in student interests and further support the creation of a well-rounded university education combining traditional and contemporary studies, the course structure was amended to allow students the opportunity to select up to four subjects from outside the course that would complement their Islamic studies. These subjects would be selected from an endorsed list and provided to students by CISAC with the aim of maintaining course cohesion. 
Endorsed subjects included astronomy, psychology and sociology, in addition to many others offered by the Faculty of Arts.

Although the centrality of the Arabic language to the study of traditional Islamic sciences cannot be undermined, demographics reveal students vary in competency at entry. Accordingly, course design was amended to limit proficiency credits in the Arabic component of the course and thereby enable students to enter at their own level and then work their way up.

A number of new subjects were added to the undergraduate course. To meet student aspirations concerning the ability to teach Islam after graduation, a 'How to serve Islam and Muslims' course was introduced, in which students would learn how to disseminate their Islamic knowledge in the context of a multicultural community in which Muslims are a minority. To better equip students with the ability to address contemporary cultural, political and religious issues centred around women, a 'Women in Society and Civilisation' subject was introduced. In this, students would become acquainted with the role and status of women in Islam, socio-political and cultural issues centred around women, and the historical challenges and achievements of women in world history (with an emphasis on Islamic history). In addition, the existing 'Prophetic History' course was amended to cover world history in parallel to the Qur'anic depiction of the prophets. A 'Religion and Belief Systems in Australia' subject was also introduced, designed to examine the world religions as they exist against the backdrop of Australia's social, political and religious history.

To complement CISAC's continued commitment to enhancing student research skills and academic abilities, and in that way promote the university's graduate attributes, a final-year 'Guided Research' subject was introduced for undergraduate students. In addition, CISAC resolved to: implement the scaffolding of assessment tasks within and between subjects, as well as between year levels; introduce a 'Logic and Critical Reasoning' subject especially geared towards academic study; offer various study and academic skills workshops throughout the semester; implement a first-year mentoring programme for new students; and offer study camps to give students an opportunity to get away from busy lives and concentrate on their studies.

A key finding of the survey was the identification of a sub-set of students who were seeking to study Islam at a scholarly level with the aim of serving as teachers, imams or other religious figures (Figure 6). To address the needs of these students, a supplementary 'Scholar Development Programme' will be developed. This programme will be designed specifically for students who fulfil some given criteria, including: Qur'anic memorisation and perfect recitation; good proficiency in the classic Arabic language; and a deeper knowledge, understanding and application of the usuli disciplines. 
In addition to the introduction of these new subjects, which will also be available to students on other courses, some changes were also made to the structure and content of the Master of Islamic Studies course. Similar to the bachelor's course, core subjects were limited to four, with the remaining being rendered as electives. To help establish a stronger grounding in traditional Islamic sciences, while also improving research, writing and critical thinking skills, the course was also increased from 1.5 years to two years for those students who have no previous formal education in Islam. The course duration would remain 1.5 years, however, for students with a prior bachelor degree in Islamic studies. The expectation was that this arrangement would better serve those students seeking to teach Islam upon graduation.

Further, in support of the teaching and academic aspirations expressed by students in the survey, various new master's level subjects were developed to better prepare students for doctoral-level study and thereby augment the scholar development programme. These subjects included: 'Research Methodology', 'Interpreting Islamic Sacred Texts', 'Islamic History, Law and Society', 'Contemporary Islamic Thought', 'Guided Research and Writing' and the 'Capstone Research Project'.

\section{Conclusion and Recommendations}

Islamic higher education in Western universities is undergoing dramatic change. For the first time, hundreds and thousands of second- and third-generation Muslims living as permanent minorities in Western societies are demanding to study Islam as a faith tradition. This demand must be met with a comprehensive and holistic delivery of traditional Islamic sciences within a modern university framework. The experiences of ISRA and Charles Sturt University's CISAC demonstrate that it is possible to combine the advantages of traditional Islamic education with the incentives and quality assurances of the Western university model.

CISAC's experience, as revealed by its recent survey, demonstrates that students who wish to study Islam are extremely diverse in terms of ethnicity, gender, age, and educational background. This diversity poses unique challenges for course design. In particular, student expectations concerning course content and outcomes vary, ranging from a desire to attain wellgrounded Islamic education for personal practice to gaining more scholarly Islamic knowledge for the purposes of teaching. Although the majority of students belong to the former group, a significant number are nevertheless represented by the latter. 
In light of the above discussion, the following recommendations are made:

1. For those students who constitute part of a Muslim minority living in a Western country, university-level Islamic studies courses should be designed as an exploration of Islam from within, as a means of providing a thorough and in depth introduction to all of the religion's traditional disciplines.

2. Since it is not possible to incorporate the entirely of traditional Islamic scholarship into a finite university course, some graduates may not have sufficient grounding in Islamic disciplines. A supplementary development programme therefore needs to be introduced to augment the bachelor's and master's courses and thereby assist those students who wish to go further in their Islamic learning.

3. Subject and unit design and delivery should creatively merge classical and contemporary content, traditional approaches and modern academic skills, revelation and reason.

4. Assessment design should take into account the diversity of the student base in order to facilitate different learning styles, and while using multiple in-class and online technologies.

5. Importantly, non-Muslim students should not be ignored. Existing models of Islamic studies in Western universities - where Islam and contemporary issues are studied from a religious, social, cultural and political standpoint - should be maintained as separate programmes.

This case study demonstrates the need for continued student engagement, coupled with course re-evaluation in light of student needs and expectations. This will better inform and improve the early stages of course design for a cohesive model of Islamic education in the West.

\section{Notes}

* Mehmet Ozalp is an associate professor of Islamic studies. He is the Director of the Centre for Islamic Studies and Civilisation at Charles Sturt University. He is an executive member of Public and Contextual Theology $(\mathrm{PaCT})$, a research centre at Charles Sturt University. He is on the Human Ethics Committee at the University of Sydney.

** Tamana Daqiq is an executive member at the Islamic Sciences and Research Academy of Australia (ISRA). 
1. Charles Kurzman and Carl W. Ernst, "Islamic Studies in US Universities", Middle East Studies Association of North America 46, no.1 (2012), 24-46.

2. Kurzman and Ernst, "Islamic Studies in US Universities", 24-46.

3. Anthony H. Johns, "Hopes and Frustrations: Islamic and Middle Eastern Studies in Australia", Middle East Studies Association of North America 25, no. 2 (1991), 173-180.

4. Yedullah Kazmi, "Islamic Education: Traditional Education or Education of Tradition?" Islamic Studies 42, (2003), 259.

5. Fazlur Rahman, "Islamization of Knowledge: A Response", Islamic Studies 50, (2011), 449-457.

6. Robert. W. Hefner, Making Modern Muslims: the Politics of Islamic Education in Southeast Asia (Honolulu: University of Hawaii Press, 2009).

7. Pohl, Florian, Islamic Education and the Public Sphere: Today's Pesantren in Indonesia (New York: Waxmann, 2009).

8. Hefner, Making Modern Muslims.

9. Pohl, Islamic Education and the Public Sphere.

10. Daniel Suryadarma and Gavin W. Jones, Education in Indonesia (Singapore: Institute of Southeast Asian Studies, 2013).

11. Ronald Lukens-Bull, Islamic Higher Education in Indonesia: Continuity and Conflict (New York: Palgrave Macmillan, 2013).

12. Christine Asmar, "A Community on Campus: Muslim Students in Australian Universities", Muslim Communities in Australia, (2001).

13. Clyne, I. Donohoue, "Seeking Education: The Struggle of Muslims to educate their children in Australia", PhD diss, (2000), University of Melbourne.

14. Christine Asmar, Elizabeth Proude and Lici Inge, "'Unwelcome Sisters?' An Analysis of Findings from a Study of How Muslim Women (and Muslim Men) Experience University", Australian Journal of Education 48, (2004), 47-63.

15. Abe Ata and Joel Windle, "The Role of Australian Schools in Educating Students about Islam and Muslims", Australian Institute of Policy and Science 79, no. 6 (2007), 19-27.

16. Kurzman and Ernst, "Islamic Studies in US Universities", 24.

17. Todd. M. Johnson, Brian J. Grim, and Gina A. Bellofatto. The World's Religions in Figures: An Introduction to International Religious Demography (Hoboken, Wiley, 2013).

18. Australian Bureau of Statistics. Australian Demographic Statistics, Sep 2013. Cat. No. 3101.0. (Canberra, ACT, Sep 2013).

19. Ata and Windle, "The Role of Australian Schools", 19.

20. Meir Hatina, "Restoring a Lost Identity: Models of Education in Modern Islamic Thought", British Society for Middle Eastern Studies 33, no. 2 (2006), 195.

21. Ata and Windle, "The Role of Australian Schools", 19.

22. Kurzman and Ernst, "Islamic Studies in US Universities", 24-9. 
23. Johns, "Hopes and Frustrations", 176.

24. Ibid., 175.

25. Christine Asmar, "A Community on Campus".

26. Kurzman and Ernst, "Islamic Studies in US Universities", 24.

27. As of June 29, 2014, Charles Sturt University website www.csu.edu.au. 